\begin{tabular}{|l|l|}
\hline Jurnal Bimbingan dan Konseling Ar-Rahman \\
Volume 6, Nomor 2, Tahun 2020 \\
Tersedia Online: http://ojs.uniska.ac.id/index.php/BKA \\
e-ISSN 2477-6300
\end{tabular}

\title{
KONTRIBUSI DUKUNGAN SOSIAL DAN EFIKASI DIRI TERHADAP PROKRASTINASI AKADEMIK PADA SISWA KELAS VII DI SMP NEGERI 27 BANJARMASIN
}

\author{
Noor Anida Rahmadina ${ }^{1}$, Sulistiyana ${ }^{2}$, Muhammad Arsyad ${ }^{3}$ \\ Program Studi Bimbingan dan Konseling, Universitas Lambung Mangkurat, Banjarmasin \\ E-mail : anidarhmadina06@gmail.com ${ }^{1}$, sulis.bk@ulm.ac.id ${ }^{2}$, arsyad.bk@ulmac.id $^{3}$
}

\begin{abstract}
ABSTRAK
Proktastinasi akademik merupakan suatu bentuk penundaan dalam menyelesaikan suatu tugas ataupun pekerjaan. Prokrastinasi akademik juga sudah menjadi problem bagi banyak orang. Maka, tujuan pada penelitian ini ialah untuk mengetahui kontribusi antara dukungan sosial dan efikasi diri terhadap prokrastinasi akademik pada siswa kelas VII di SMP Negeri 27 Banjarmasin. Penelitian ini menggunakan pendekatan kuantitatif dengan jenis penelitian kontribusi. Alat pengumpulan data menggunakan angket dan teknik penarikan sampel menggunakan sampel jenuh. Adapun, sampel yang diambil sebanyak 193 orang siswa kelas VII di SMP Negeri 27 Banjarmasin. Dengan teknik analisis data menggunakan regresi linear sederhana dan regresi liniear berganda. Hasil dari Teknik analisis data menggunakan Uji Regresi Liniear Berganda mendapatkan hasil bahwa nilai sig 0,000 > 0,05 dan nilai $F_{\text {hitung }} 381,356$ yang dinyatakan ada kontribusi yang signifikan antara dukungan sosial dan efikasi diri terhadap prokrastnasi akademik dikalangan siswa kelas VII di SMP Negeri 27 Banjarmasin. Adapun dari hasil analisis yang ditemukan menyatakan bahwa dukungan sosial dan efikasi diri memberikan kontribusi terhadap prokrastinasi akademik sebesar $80,1 \%$.
\end{abstract}

Kata Kunci: Dukungan Sosial; Efikasi Diri; Prokrastinasi Akademik

\begin{abstract}
Academic procastination is a form of delay in completing a task or job. Academic procrastination has also become a problem for many people. So, the purpose of this study was to describe the social support and self-efficacy of academic procrastination in grade VII students at SMP Negeri 27 Banjarmasin. And to determine the contribution between social support and self-efficacy on academic procrastination in grade VII students at SMP Negeri 27 Banjarmasin. This study uses a quantitative approach with the type of research contribution. The data collection tool used a questionnaire and the sampling technique used saturated sample. The sample taken was 193 grade VII students at SMP Negeri 27 Banjarmasin. With data analysis techniques using simple linear regression and multiple linear regression.The results of the data analysis technique using the Multiple Linear Regression Test show that the sig value is $0.000>0.05$ and the Fcount value is 381.356 which states that there is a significant contribution between social support and self-efficacy on academic procrastination among seventh grade students at SMP Negeri 27 Banjarmasin. The results of the analysis found that social support and self-efficacy contributed $80.1 \%$.
\end{abstract}

Keywords: Social Support; Self-Efficacy; Academic Procrastination 
Noor Annida Rahmadina, Sulistiyana, Muhammad Arsyad Jurnal Bimbingan dan Konseling Ar-Rahman Volume 6, Nomor 2, Tahun 2020

e-ISSN 2477-6300

\section{PENDAHULUAN}

Belajar adalah suatu tugas utama yang harus dilakukan oleh seorang siswa, akan tetapi tidak semua siswa memiliki pengelolaan belajar yang baik, khususnya dalam pengelolaan waktu. Berdasarkan fenomena yang terdapat didalam sebuah artikel Fauzi (2016 dalam Tirto.Id) yang menyebutkan bahwa, sekarang memang terdapat beberapa siswa yang belum mampu mengatur waktu dengan baik. Hal tersebut dapat menyebabkan, mereka akan menunda-nuda suatu tugas ataupun pekejaan yang mereka miliki (diakses pada 6 Agustus 2019). Dari penjelasan di atas didukung dengan hasil penelitian Muyana (2018: 45) yang menjelaskan bahwa, tingkat menundanunda siswa dalam suatu tugas berada pada kategori tinggi sebanyak $81 \%$.

Maka dari itu menunda-nunda suatu tugas ataupun pekerjaan sudah menjadi problem bagi banyak orang. Saat memiliki tugas yang seharusnya diselesaikan dengan segera, malah sering dikesampingkan. Menurut kajian psikologi, fenomena diatas biasanya disebut dengan prokrastinasi akademik. Sedangkan, pokrastinasi akademik menurut Brown dan Holzman adalah suatu kecenderungan menunda-nunda dalam hal menyelesaian tugas ataupun pekerjaan (Ghufron, 2017: 151).

Prokrastinasi akademik yang terjadi pada siswa terjadi karenai siswa suka menunda-nunda mengerjakan tugas sampai batas waktu pengumpulan dengan memberi alasan untuk memperole tambahan waktu atau tidak menyukaia tugasnya dan memilih untuk melakukan kegiatan lain yang lebih menyenangkan seperti menontot televisi, jalan-jalan, dan sebagainya (Styawan, 2015).

Sekitar $25 \%$ sampai dengan $75 \%$ dari pelajari melaporkan bahwa prokrastinasi merupakan salah satu masalah dalam lingkup akademis mereka (Ghufron, 2010). Munwarrah (2017: 26) juga menyebutkan bahwa di SMP Muhammadiyah 9 Yogyakarta juga terdapat tingkat prokrastinasi akademik yangg tinggi. Hal tersebut serupa dengan hasil penelitian Surijah (2007: 368) yang menyatakan bahwa terdapat $30,9 \%$ siswa berada pada tingkat very high procrastinator.

Prokrastinasi akademik ini juga di pengaruhi oleh berbagai macam faktor. Menurut Feraril (dalam Fauziah, 2015:128) faktor prokrastinasi akademik ini dikelompokkan menjadi 2 yaitu faktor internal dan faktor eksternal. Adapun faktor internal meliputi kondisi fisik dan psikologis, sedangkan faktor eksternal meliputi pola pengasuhan orang tua, dukungan sosial, reward dan punishment, serta tugas terlalui banyak. Dari beberapa faktor yang telah dipaparkan maka dari itu salah satu faktor yang dapat mempengaruhi prokrastinasi akademik yaitui dukungan sosial.

Menurut Sarafino (2011: 84) dukungan sosial adalahh suatu pandangan terhadap kenyamanan, perhatian, penghargaan ataupun bantuanj yang diterima individu dari orang lain. Adapunk jenis dari dukungan sosial yaitu dukungan emosional, dukungan penghargaan, dukungan intrumental serta dukungan informatif. Penelitian (Fauziah, 2015: 128) juga menyatakann bahwa dukungan sosial memangm sangati mempengaruhi prokrastinasi akademik, apabilak dukungan sosialnya tinggi maka tingkat prokrastinasi akademik cenderung akan rendah, begitu pula sebaliknya apabila dukungan sosial rendah maka tingkat prokrastinasi akademik cenderung akan tinggi.

Salah satu faktor lain, yang dapat mempengaruhi prokrastinasi akademik yaitu keadaani psikologis. Adapun keadaan psikologis ini juga salah satu faktor pembentuk dari efikasi diri. Menurut Bandura efikasi diri adalah suatu keyakinan individu terhadap kemampuan dirinya dalam melakukan tugas atau tindakan yang diperlukan untuk mencapai hasil yang diinginkan (Ghufron, 2017: 73). Seseorang yang mempunyai efikasi diri rendah dalam menghadapi tantangann akan berkurang atau bahkan menyerah, sementara orang yang mempunyai efikasi diri tinggi maka akan berusaha lebih keras untuk meraih kesempatan (Widanarti, 2002).

Berdasarkan dari problematika yang ada di lapangan maka tujuan dari penelitian ini untuk menganalisis seberapa besar kontribusi dukungan sosial dan efikasi diri terhadap prokrastinasi akademik. Maka dari itu peneliti mengambil judul "Kontribusi Dukungan Sosial dan Efikasi Diri Terhadap Prokrastinasi Akademik Pada Siwa Kelas VII Di SMP Negeri 27 Banjarmasin”.

\section{METODE}

Penelitian ini terdapat 3 variabel penelitian yaitu variabel Dukungan Sosial $\left(\mathrm{X}_{1}\right)$, Efikasi diri $\left(\mathrm{X}_{2}\right)$ dan Prokrastinasi Akademik (Y).

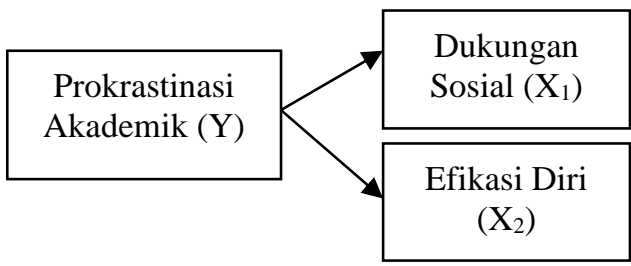

\section{Gambar 1. Bagan Variabel Penelitian}

Penelitian ini memiliki hipotesis bahwa (1) ada kontribusi antara dukungan sosial terhadap prokrastinasi akademik di SMP Negeri 27 
Noor Annida Rahmadina, Sulistiyana, Muhammad Arsyad

Jurnal Bimbingan dan Konseling Ar-Rahman

Volume 6, Nomor 2, Tahun 2020

e-ISSN 2477-6300

Banjarmasin; (2) ada kontribusi antara efikasi diri terhadap prokrastinasi akademik di SMP Negeri 27 Banjarmasin; (3) ada kontribusi antara dukungan sosial dan efikasi diri terhadap prokrastinasi akademik di SMP Negeri 27 Banjarmasin. Untuk menjawab hipotesis tersebut digunakan teknik regresi linier berganda.

Secara khusus, penelitian ini mencari tahu seberapa besar kontribusi antara dukungan sosial dan efikasi diri (variabel bebas) terhadap prokrastinasi akademik (variabel terikat). Populasi dari penelitian ini adalah seluruh siswa kelas VII di SMP Negeri 27 Banjarmasin dengan jumlah 193 orang. Sedangkan teknik penarikan sampel menggunakan sampel jenuh dengan menjadikan seluruh populasi menjadi sampel. Adapun sempel dalam penelitian ini berjumlah 193 siswa. Data penelitian dikumpulkan menggunakan skala likert pada setiap variabel terikat dan variabel bebas. Pengujian intrumen menggunakan rumus product moment dengan bantuan komputer Microsoft Exel 2007 dan SPSS Statistical Product and Service Solution) Versi 25.

Adapun, angket dukungan sosial disusun dengan 6 indikator yaitu (1) dihargai; (2) dicintai; (3) diperhatikan; (4) memberikan nasihat; (5) memberikan pengetahuan, dan (6) memberikan bantuan. Dalam setiap indikator terdapat 35 item pernyataan yang terdiri dari favorebel sebanyak 12 item dan unfavorebel sebanyak 23 item pernyataan.

Angket efikasi diri disusun dengan 3 indikator yaitu (1) siswa yakin untuk mengatasi tugas-tugas yang memiliki tingkat kesulitan yang tinggi; (2) siswa memiiki ketekunan dalam mencaai tujuan, dan (3) siswa memiliki keyakinan diri atas kemampuan yang dimiliki dalam menghadapi berbagai macam tugas. Dalam setiap indikator terdapat 32 item pernyataan yang terdiri dari favorebel sebanyak 19 item dan unfavorebel sebanyak 13 item pernyataan.

Sedangkan, angket prokrastinasi akademik disusun dengan 4 indikator yaitu (1) menunda untuk menyelesaikan tugas; (2) keterlambatan dalam mengerjakan tugas; (3) kesenjangan waktu antara bekerja dan kinerja, dan (4) melakukan aktivitas yang lebih menyenangkan. Dalam setiap indikator terdapat 40 item pernyataan yang terdiri dari favorable sebanyak 22 item dan unfavorable sebanyak 18 item pernyaatan.

Tabel 1. Coefficients Alpha

\begin{tabular}{cccc} 
Model & $\begin{array}{c}\text { Cronbach's } \\
\text { Alpha }\end{array}$ & $\begin{array}{c}\mathbf{r}_{\text {tabel }} \\
\mathbf{5 \%}\end{array}$ & Keterangan \\
\hline $\mathrm{X}_{1}$ &, 938 & 0,361 & Reliabel \\
$\mathrm{X}_{2}$ &, 898 & 0,361 & Reliabel \\
$\mathrm{Y}$ &, 971 & 0,361 & Reliabel \\
\hline
\end{tabular}

Sebelum angket disebarkan kepada siswa, angket di uji validitas dan reabilitasnnya dengan menggunakan alpha cronbach. Hasil uji validitas dan reabilitas angket dukungan sosial sebesar 0,938. Angket efikasi diri menunjukkan nilai sebesar 0,898 , begitu pula angket prokrastinasi akademik juga menunjukkan nilai sebesar 0,971. Berdasarkan hasil uji validitas dan reabilitas ini dapat di simpulkan bahwa ketiga angket tersebut layak untuk digunakan.

Dengan hasil tersebut, selanjutnya instrument disusun kembali untuk digunakan sebagai alat pengumpul data. Dalam penelitian ini menggunakab uji regresi linear berganda dengan taraf signifikas $<0,005$.

\section{HASIL DAN PEMBAHASAN}

Berdasarkan hasil dari analisis data yang telah dilakukan oleh peneliti menunjukkan bahwa hipotesis diterima, yaitu terdapat kontribusi antara efikasi diri dan dukungan sosial terhadap prokrastinasi akademik. Hasil uji hipotesis menunjukan bahwa terdapat kontribusi antara dukungan sosial terhadap prokrastinasi akademik dengan nilai signifikan sebesar $0,000<$ 0,05 .

Hasil analisis regresi berganda, yang ditunjukkan oleh tabel Anova diketahui bahwa memiliki kontribusi dukungan sosial $\left(\mathrm{X}_{1}\right)$ dan efikasi diri $\left(\mathrm{X}_{2}\right)$ terhadap prokrastinasi akademik (Y). Pada kolom R Square menunjukkan nilai sebesar 0.801 yang berarti variabel dukungan sosial $\left(\mathrm{X}_{1}\right)$ dan efikasi diri $\left(\mathrm{X}_{2}\right)$ berkontribusi sebesar $80,1 \%$, seperti yang di tunjukkan dalam tabel 2 dan 3.

Tabel 2. Hasil Uji ANOVA

\begin{tabular}{cccc}
\hline Model & Mean Square & F & Sig. \\
\hline Regression & 3163,863 & 381,3 &, 000 \\
Residual & 8,296 & 56 & \\
\hline Total & & &, 000 \\
\hline
\end{tabular}

a. Dependent Variable: Prokrastinasi Akademik

b. Predictors: (Constant), Dukungan sosial, Efikasi Diri 
Noor Annida Rahmadina, Sulistiyana, Muhammad Arsyad Jurnal Bimbingan dan Konseling Ar-Rahman

Volume 6, Nomor 2, Tahun 2020

e-ISSN 2477-6300

Tabel 3 : Kontribusi $X_{1}$ dan $X_{2}$ Terhadap Y Model Summary

\begin{tabular}{cccc}
\hline Model & $\boldsymbol{R}$ & R Square & Adjusted R Square \\
\hline 1 &, $895^{\mathrm{a}}$ &, 801 &, 798 \\
\hline
\end{tabular}

a. Predictors: (Constant), Dukungan Sosial, Efikasi Diri

b. Dependent Variabel: Prokrastinasi Akademik

Dari hasil yang didapatkan peneliti di lapangan sejalan dengan penelitian yang dilakukan oleh Febrianti (2009: 11) yang menyatakan bahwa terdapat hubungan yang signifikan antara dukungan sosial dengan prokrastinasi akademik. Penelitian yang dilakukan oleh Lumbantobing (2016: 34) juga menemukank bahwa dukungan sosial memiliki hubungan negatif yang signifikan dengan prokrastinasi. Artinyaa semaki tinggi tingakat dukungan sosial, maka semakin rendah pula tingkat prokrastianasi akademiknya, begitu pula sebaliknya.

Dukungan sosial bagi setiap orang pada dasarnya tidak selalu memberikan dampak positif seperti yang diharapkan oleh setiap individu efek dari dukungan sosial pada setiap individu berbedabeda, tergantung bagaimana individu mempersepsikan dukungan sosial tersebut, sehingga mempengaruhi kognisi, serta emosi yang memunculkan suatu perilaku. Stansfeld (2002) menyatakan dukungan sosial itu dapat memberikan efek yang baik dan sesuai jika diberikan dalam situasi dan kondisi yang tepat. Oleh karena itu, dukungan dari orang-orang yang ada disekitar individu seperti orang tua, keluarga, teman, sahabat, dan lain-lain sangat penting karena hal tersebut dapat mempengaruhi tingkat prokrastinasi akademik siswa.

Hasil uji hipotesis kedua menunjukkan bahwa adanya kontribusi antara efikasi diri terhadap prokrastinasi akademik pada siswa kelas VII di SMP Negeri 27 Banjarmasin dengan nilai signifikansi sebesar $0,000<0,05$. Artinya semakini tinggi efikasi diri siswa maka semakin rendah tingkat prokrastinasi akademiknya, begitu pula sebaliknya. Semakin rendah efikasi dirinya maka semakin tinggi pula tingkat prokrastinasi akademik yang siswa rasakan.

Hal tersebut sejalan dengan penelitian yang telah dilakukan oleh Pratiwii dan Sawitri (2015) pada 227 mahasiswa. Menunjukkan hubungan negatif yang signifikan antara efikasi diri dengan prokrastinasi akademik. Hal ini sejalan dengan penelitian yang dilakukan oleh Khotimah (2016) pada 393 siswa menunjukan bahwa efikasi diri. dan prokrastinasi akademik memiliki hubungan yang signifikan.

Efikasi diri ini sangat berperan penting pada usaha yang dilakukan seseorang dalam setiap aktivitasnya, efikasi diri berperan penting dalam menentukan sikap setiap individu untuk bertindak, berfikir, dan beraksi dalam mengahadapi berbagai macam masalah. Individui yang memiliki keyakinan yang tinggi akan dirinya cenderung tidak akan melakukan perilaku prokrastinasi, sementara seseorang yang tidak yakin terhadap kemampuannya cenderung melakukan prokrastinasi. Sejalan dengan apa yang diungkapkan oleh Wäschle, dkk. (dalam Ghufron, 2017) bahwa jika efikasi diri yg seseorang tinggi akan membuatnya yakin pada kemampuan yang dimiliki untuk menyelesaikan suatu tugas. Namun jika efikasi dirinya rendah cenderung menunda dan menghindari suatu tugas ataupun pekerjaan.

Menurut Bandura (dalam Ghufron, 2017) salah satu proses yang mempengaruhi efikasi diri ialah proses kognitif kebanyakan perilaku manusia bermula dari sesuatu yang difikirkan. Seseorang yang memilikii efikasi diri yang tinggi adalah seseorang yang selalu bersemangat dalam melakukan segala hal dan juga pantang menyerah, sebaliknya seseorang yang efikasi dirinya rendah lebih banyak membayangkann kegagalan dan mudah untuk menyerah apabila dihadapkan dalam suatu masalah.

Hasil uji hipotesis selanjutnya menunjukkan kontribusi antara dukungan sosial dan efikasi diri dengan prokrastinasi akademik memperoleh hasil signifikan sebesar 0,000<0,05. Artinya, semakin baik dan tingginya dukungan sosial dan efikasi diri, maka akan dapat mampuk mengurangi perilaku prokrastinasi akademik. Terdapat beberapa variabel yang mempengaruhi prokrastinasi, namun pada penelitian ini lebih difokuskan pada dukungan sosial dan efikasi diri, seperti yang terdapat di dalam penelitian Rahayu (2018) menunjukan bahwa terdapat hubungan yang signifikan antara efikasi diri dan dukungan sosial dengan prokrastinasi akademik.

\section{PENUTUP}

Dari hasil yang telah didapatkan di lapangan maka dapat disimpulkan bahwa: (1) dukungan sosial memberikan kontribusi terhadap prokrastinasi akademik pada siswa kelas VII di SMP Negeri 27 Banjarasin; (2) efikasi diri memberikan kontribusi terhadap prokrastinasi akademik pada siswa kelas VII di SMP Negeri 27 
Noor Annida Rahmadina, Sulistiyana, Muhammad Arsyad

Jurnal Bimbingan dan Konseling Ar-Rahman

Volume 6, Nomor 2, Tahun 2020

e-ISSN 2477-6300

Banjarasin; (3) dukungan sosial dan efikasi diri memberikan kontribusi terhadap prokrastinasi akademik pada siswa kelas VII di SMP Negeri 27 Banjarasin sebesar $80,1 \%$.

Berdasarkan hasil penelituan tersebut, dapat disarankan kepada kepala sekolah agar lebih memperhatikan dukungan sosial dan efikasi diri siswa, karena dua hal tersebut dapat berpengaruh terhadap prokrastinasi akademik siswa. Kepada guru BK dapat disarankan untuk memberikan layanan yang terkait dengan dukungan sosial dan efikasi diri, sehingga dapat mengurangi prokrastinasi akademik. Bagi peneliti selanjutnya diharapkan untuk mengkaji lebih banyak sumber maupun referensi terkait dengan masalah yang di ambil, agar nantinya hasil penelitian yang diperoleh dapat lebih baik dan lebih lengkap. Peneliti selanjutnya juga di harapkan lebih mempersiapkan diri perihal kendala-kendala dalam proses pengambilan dan pengumpulan data kelapangan, sehingga penelitian dapat dilaksanakan dengan lancar.

\section{REFERENSI}

Fauzi, R. (2016, 18 Desember). Melawan Kebiasaan Menunda-nunda Pekerjaan. Tirto.id (Online). (Diakses dari https://tirto.id/melawan-kebiasaanmenunda-nunda-pekerjaan-b9YW,6 6 Agustus 2019).

Fauziah, H.H. (2015). Faktor-faktor yang Mempengaruhi Prokrastinasi Akademik Pada Mahasiswa Fakultas Psikologi UIN Sunan Gunung Djati Bandung. Jurnal Ilmiah Psikologi. 2 (2): 123-132.

Febrianti, D.I. (2009). Hubungan Antara Dukungan Sosial Orang Tua dengan Prokrastinasi Akademik dalam Menyelesaikan Skripsi Pada Mahasiswa Fakultas Psikologi. Skripsi pada Sarjana Psikologi. Universitas Dipenogoro Semarang: tidak diterbitkan.

Ferari, R.J. (2010). Still Procrastinating? The NoRegrets Guide to Getting It Done. New York: Wiley.

Ghufron, N.M \& Risnawati. (2017). Teori-teori Psikologi. Jogjakarta: Ar-ruzz Media

Khotimah, H.R. \& Radjah, L.C. (2016). Hubungan Antara Konsep Diri Akademik, Efikasi Diri Akademik, Harga Diri dan Prokrastinasi Akademik Pada Siswa SMP Negeri di Kota Malang. Jurnal Kajian Bimbingan dan Konseling. 1 (2): 60-67.

Lumbantoubing, P. A. (2016). Hubungan Adversity Quotient Dan Dukungan Sosial Dengan Prokrastinasi Akademik Dalam Penyelesaian Skripsi Pada Mahasiswa Yang
Bekerja Di Pts Stmik-Stie Mikroskil Medan. Jurnal Mutiara Pendidikan Indonesia. 1 (1): 1-14.

Muyana. (2018). Problematika menunda-nunda siswa SMP Malang. Jurnal Ilmiah Psikologi. 1 (2): 45-49.

Pratiwi, D.A. \& Sawitri, R.D. (2015). Prokrastinasi Akademik Ditinjau dari Efikasi Diri Akademik dan Lama Studi Pada Mahasiswa Jurusan Desain Komunikasi Visual Universitas Dian Nuswantoro. Jurnal Empati. 4 (4): 272-276.

Rahayu, A. (2018). Hubungan Dukungan Sosial Dan Konsep Diri Dengan Penyesuaian Diri Remaja Kelas X SMA Angkasa I Jakarta. Jurnal Sosial Dan Humaniora. 2 (2) : $75-81$.

Stansfeld, S. (2002). Social support measurement and intervention: A guide for health and social scientists. International Journal of Epidemiology, 31(3), 698-698.

Styawan. (2015). Hubungan Antara Asertivitas dengan dengan Prokrastinasi Akademik Pada Mahasiswa Fakultas Psikologi Universitas Diponegoro Semarang. Naskah Publikasi, (Online). 